\title{
Is there a role for wine in cancer and the degenerative diseases of aging?
}

\author{
This article was published in the following Dove Press journal: \\ International Journal of Wine Research \\ 25 June 2009 \\ Number of times this article has been viewed
}

\section{Creina S Stockley \\ The Australian Wine Research Institute, Adelaide, South Australia, Australia}

Correspondence: Creina S Stockley PO Box 197, Glen Osmond 5064, South Australia, Australia

$\mathrm{Tel}+61883136612$

Fax +61883136600

Email creina.stockley@awri.com.au

\begin{abstract}
Population aging is associated with the increased incidence cancer and of degenerative diseases. Population aging is occurring on a global scale, with faster aging projected for the coming decades than has occurred in the past. Globally, the population aged 60 years and over is projected to nearly triple by 2050 , while the population aged 80 years and over is projected to experience a more than fivefold increase. Increased numbers of older individuals may have implications for associated expenditure on income support, housing and health services, although a healthy, independent older population can also form a valued social resource, for example in providing care for others, sharing skills and knowledge, and engaging in volunteer activities. Simple dietary measures such as moderate wine consumption to supplement a healthy exercise and nutrition routine, or as an adjunct to prescription medicines when appropriate, are thus needed to maintain an aging population. The role of wine in cancer and the degenerative diseases of aging is thus discussed.
\end{abstract}

Keywords: population aging, wine, degenerative disease, cancer

\section{Introduction}

Damage to DNA, lipids, and proteins by reactive oxygen species (oxidative free radicals) has been implicated in accelerated aging, degenerative diseases including cancer, ${ }^{1}$ Alzheimer's disease ${ }^{2,3}$ and Parkinson's disease, ${ }^{4}$ as well as cardiovascular disease. These diseases of old age are expected to increase significantly over the next few decades as people increasingly survive beyond the age of 80 years. ${ }^{5}$ Consequently there is interest in identifying lifestyle factors and molecular mechanisms that can minimize the risk of these debilitating conditions.

There is a clear J-shaped relationship between alcohol consumption and the risk of cardiovascular disease which has been extended to a reduced risk of certain cancers. ${ }^{6-8}$ Data is now accumulating which suggests that the regular and moderate consumption of alcohol may reduce the risk of Alzheimer's disease, bone mineral density, chronic obstructive airways disease, diabetes, disorders of the immune system, gallstones, gastrointestinal diseases, kidney stones, osteoporosis, rheumatoid arthritis, and agerelated visual impairment, or macular degeneration in addition to psychological or social benefits. ${ }^{9-20}$ While the literature defines consistently light to moderate consumption as 20 to $40 \mathrm{~g}$ alcohol/day, ${ }^{21-24}$ several studies have defined moderate consumption as up to $80 \mathrm{~g}$ alcohol/day for men, ${ }^{25,26}$ which may reflect country and cultural differences in alcohol consumption. ${ }^{27}$ Above moderate consumption the risk of alcohol-related diseases increases dose-dependently. ${ }^{28}$ The chemical components of wine purportedly primarily responsible for these therapeutic effects are ethanol and the 
monomeric phenolic compounds and their polymeric forms. The ethanol component is common to all alcoholic beverages. At the same time as the therapeutic effects of the phenolic compounds are observed, however, the phenolic compounds appear to undergo extensive first-pass phase II metabolism in the small intestine and in the liver. ${ }^{29}$ Metabolites conjugated with methyl, glucuronate, and sulfate groups are the predominant forms present in plasma, but these are usually not measured in human clinical studies,${ }^{30}$ although they actually be the biologically active chemical components. The paucity of human data, in particular, on the pharmacokinetics and pharmacodynamics of the phenolic compounds and their metabolites warrants more research, using escalating doses in accurately controlled human clinical studies in conjunction with reliable and established biomarkers.

\section{Wine consumption and the risk of cancer}

Alcohol consumption per se has been associated with an increased risk of developing cancer of the mouth, pharynx, esophagus, stomach, liver, colon and rectum. ${ }^{31-34}$ The level of alcohol consumption that increases risk has not been determined and there are usually other risk factors for cancer, which confound determination. ${ }^{35}$ The risk of cancer of the mouth, tongue and larynx, however, is associated with the number of alcoholic drinks per day. While it is unlikely that alcohol itself causes cancer to develop, alcohol may act in conjunction with other cancer-inducing compounds or carcinogens. Indeed, both while alcohol consumption and smoking both independently increase the risk of these cancers, the risk is amplified if individuals both drink and smoke. ${ }^{36-38}$ In addition, alcohol consumption has been associated with an increased risk of breast cancer, particularly in women who have a family history of breast cancer. ${ }^{39-47}$ From a pooled analysis of data, the relative risk increases by 1.09 for each $10 \mathrm{~g}$ alcohol (equivalent to one standard drink) consumed per day up to $60 \mathrm{~g}$. Consumption above $60 \mathrm{~g} /$ day is not associated with a further increased risk. ${ }^{48,49}$ It has been suggested that consumption patterns may modify risk, ${ }^{50}$ such that the consumption of 40 to $50 \mathrm{~g}$ alcohol/session may increase the risk by $50 \%$ compared to the consumption of only one $10 \mathrm{~g}$ alcohol/session. Paradoxically, alcohol dependence does not increase the risk of breast cancer. ${ }^{51}$

Regular and moderate wine consumption has, however, been associated with a decreased risk of mortality from certain cancers, ${ }^{6,52}$ although the risk increases progressively with immoderate consumption. Briggs and colleagues, ${ }^{53}$ for example, calculated that the moderate consumption of wine decreased the risk of non-Hodgkin's lymphoma by approximately $20 \%$ to $40 \%$, in particular in individuals who began consuming wine as young adults, and similar decreases in risk were observed for aerodigestive tract and lung cancers. ${ }^{54-56}$ The light to moderate consumption wine decreased the risk of lung cancer in contrast to beer and spirits $^{57}$ Also in contrast to beer and spirits, the moderate consumption of wine shows null associations with, or reduces the risk of colorectal cancer at three subsites (proximal colon, distal colon, and rectum). ${ }^{52,58}$ The risk of prostate cancer was observed only to increase above a threshold of $40 \mathrm{~g}$ alcohol in the form of red wine per week. ${ }^{59}$ Renaud and colleagues ${ }^{18}$ suggested, however, that the risk of mortality from all cancers may be decreased by approximately $20 \%$ when $20 \mathrm{~g}$ alcohol in the form of wine are consumed daily.

Genetic damage is a risk factor for the formation and progression of cancer. ${ }^{1}$ Oxidative free radicals also cause mutation of DNA sequences and breakage of DNA strands. ${ }^{60}$ For example, when the genetic material or DNA of cells is damaged, the characteristics of the cell are altered causing it to malfunction or die. It is the excess occurrence of dead cells and mutant cells in the body that ultimately accelerates diseases of old age. A number of factors may contribute to this damage, including chemical genotoxins, lifestyle factors (diet, exercise and the environment), and medical therapies including radiotherapy and cytotoxic drugs. Oxidizing agents such as hydrogen peroxide and ionizing radiation cause chromosome breakage and loss, as well as cell death. ${ }^{61,62}$

\section{Potential mechanism of action: Role of wine-derived phenolic compounds on DNA}

A diet high in fruit and vegetables has been associated with a reduced risk of cancer, and this has prompted researchers to investigate whether any of the wine-derived phenolic compounds might protect cells and DNA from damage leading to cancer by inhibiting the oxidizing agents. ${ }^{1,63-65} \mathrm{~A}$ link between cardiovascular disease and cancer is an elevated micronucleous frequency, which is a biomarker of DNA damage. ${ }^{66}$ The results from numerous in vitro and animal studies suggest that individual and collective wine-derived phenolic compounds may be protective against DNA damage. Fenech and colleagues ${ }^{67}$ showed that following the acute consumption of red or white wine there was a significant increase in the antioxidant capacity of plasma, which reduced the oxidative damage to DNA from hydrogen peroxide in vitro and ex vivo. This was the first evidence that moderate wine consumption 
could minimize the DNA-damaging effects of oxidizing agents. The observation that the duration of this protective effect was diminished by eight hours post-consumption, implied that the regular consumption of wine is important to maintain a protective effect. Leighton and colleagues, ${ }^{68}$ using different biomarkers of DNA damage, has also recently shown that the short-term consumption of red or white wine, in particular in combination with a Mediterranean diet, could significantly reduce DNA damage in both elderly men and women. Interestingly, the women consumed half the amount of wine consumed by the men but showed a similar reduction in extent of DNA damage. No cellular mechanism of action has, however, been determined.

Greenrod and Fenech ${ }^{69}$ demonstrated that although ethanol exacerbated oxidative stress and hence DNA damage, the wine-derived phenolic compounds significantly countered the oxidative stress as well as the additive effects of ethanol; DNA damage was reduced by approximately $45 \%$ at approximately two hours post-consumption when de-alcoholized wine was consumed in moderation. Whole red wine also reduced DNA damage but to a lesser extent. Two studies were undertaken and the first was an in vitro study which tested human plasma or whole blood from four healthy male subjects aged 20-25 years that was spiked with different wine components for protection against hydrogen peroxide and ionizing radiation induced DNA damage. The components examined were ethanol, glycerol, tartaric acid, and caffeic acid/catechin mixture and compared to a Riesling wine stripped of phenolic compounds and a control salt solution, which was a diluent for the wine components. The components were added at $2.5 \%$ and $10 \%$ of the concentration observed in wine, where $2.5 \%$ corresponds to the concentration observed in the body fluids of a $60 \mathrm{~kg}$ volunteer after consuming 300 $\mathrm{mL}$ (approximately three glasses) of white wine. The cells were then analyzed via the cytokinesis block micronucleus assay, which enables chromosome or DNA damage to be scored. ${ }^{70}$

Greenrod and Fenech ${ }^{69}$ observed that the phenolic compounds, such as catechin and caffeic acid, and the mixture including these components, significantly decreased baseline DNA damage and DNA damage caused by ionizing radiation in vitro. It was observed that the ethanol component significantly increased base-line DNA damage, but the mixture that included both ethanol and the phenolic compounds completely countered the DNA damaging effects of ethanol. These effects were observed for both the $2.5 \%$ and $10 \%$ concentration of the components, although the protective effect of the phenolic compounds was most significant for the $10 \%$ concentration. The component mixtures, also produced the strongest protective effects against DNA damage by hydrogen peroxide. The protective effects of the mixture did not account for the expected additive protective effects of the individual components, which suggests that the components may be exerting their effects through similar mechanisms, which are saturated at the concentration tested. These observations suggest that the primary phenolic components of wine can reduce the DNA damaging effects of two important oxidants, hydrogen peroxide and ionizing radiation, in a physiologically relevant in vitro system.

The second study undertaken by Greenrod and Fenech ${ }^{71}$ was an ex vivo study in which blood from six healthy male subjects analyzed for its resistance to DNA damage induced by hydrogen peroxide or ionising radiation, following the consumption of $300 \mathrm{~mL}$ red wine, dealcoholized red wine or a model wine (12\% alcohol solution). The subjects were placed on a plant phenolic compound free diet for 48 hours prior to each study day. The results of this study showed a clear protective effect of the dealcoholized red wine, an aggravating or negative effect of ethanol and an intermediate but protective effect of whole red wine. The most significant protective effects were observed at two hours post consumption. These results were important in verifying that it is the phenolic component of wine that has DNA-protective properties in blood and body tissues.

A DNA-protective effect against the hepatic carcinogen or oxidizing agent, 2-nitropropane, was also observed in a rat animal model administered with a mixture of wine of phenolic compounds, ${ }^{72}$ but was not observed against 2-dimethylhydrazine, which is a colon carcinogen. These results imply that the phenolic component may not protect DNA against all oxidizing agents.

\section{Potential mechanism of action: Role of wine-derived phenolic compounds on cell cycle and apoptosis}

Other researchers have examined the effect of specific wine-derived phenolic compounds on cancer, in particular, resveratrol (stilbene), quercetin (flavonol), catechin (flavanols) and gallic acid (hydroxybenzoic acid). These wine-derived phenolic compounds appear capable of inhibiting cellular events at each of the three steps involved in the development of cancer: initiation, promotion, and 
progression. Experimental approaches include cell lines, (whole) animal cancer models and human cancer patients. For example, quercetin has demonstrated chemopreventative activity in azoxymethane-induced colorectal cancer in mice and male F344 rats, ${ }^{73}$ while catechin protected against the heterocyclic amine 2-amino-3-methyl-imidazo[4,5-f] quinoline (IQ)-induced aberrant crypt formation in male F344 rats. ${ }^{74}$

Other plausible mechanisms for the potential cancer-protective effects of the wine-derived phenolic compounds include: inhibition of the cell growth or proliferation resulting from arrestation at one or more phases of the cell cycle, which then activates apoptosis of cells; inhibition of DNA synthesis by inhibiting ribonucleotide reductase or DNA polymerase; and apoptosis by modulation of signal transduction pathways that regulate the cell cycle, by altered expression of primary enzymes such as cyclooxygenases and protein kinases, including modulation of tumor suppressor genes. ${ }^{75-77}$ These are in addition to the removal of reactive oxygen species.

Resveratrol appears to have been the most widely examined phenolic compound over the past decade. In 1997, Jang and colleagues observed that $1-25 \mu \mathrm{M}$ resveratrol inhibited the initiation and promotion of hydrocarbon-induced skin cancer in a mouse model as well as the progression of breast cancer in the same model. In human cancer cell lines, resveratrol has been observed to inhibit or suppress the growth and proliferation of, for example, breast, colon, prostate and oral squamous cancer cell lines. ${ }^{78-84}$ These studies also suggest that the DNA-protective effect of resveratrol is dosedependent. Latruffe and colleagues ${ }^{85}$ examined the effect of resveratrol on two different human tumor cell lines, and has shown that resveratrol is actually taken up by the cells, whereupon it is conjugated and released into the cell medium by the hepatic HepG2 cells and to a lesser extent by colorectal tumor SW480 cells. ${ }^{21}$ Phenolic compounds may not be antiproliferative or active against all tumor cell lines, however, as no uptake and conjugation was observed with cells from the intestine. Elattar and Virji ${ }^{78}$ examined the effect of quercetin alone and in combination with resveratrol on human oral squamous carcinoma cells (SCC-25), and showed that quercetin is an equipotent inhibitor of SCC-25 cell growth and DNA synthesis, but the combination of quercetin and resveratrol was most potent. ${ }^{86}$

Studies have shown that resveratrol also possesses chemopreventative activity against colorectal cancer. ${ }^{87,88}$ Schneider and colleagues ${ }^{87}$ showed that treatment of CaCo-2 human colon tumor cells with $25 \mu \mathrm{M}(5.7 \mathrm{mg})$ resveratrol inhibited cell growth by $70 \%$. The cells accumulated at the S/G2 phase transition of the cell cycle. Furthermore, resveratrol significantly decreased the activity of the polyamine biosynthesis enzyme, ornithine decarboxylase, which is enhanced in tumor cell growth. Wolter and colleagues ${ }^{88}$ showed that inhibition of cell CaCo-2 human colon tumor cells with resveratrol was dose-dependent $(12.5-200 \mu \mathrm{M}){ }^{88}$ A lower concentration of resveratrol $(50 \mu \mathrm{M})$ perturbed cell cycle progression from the $\mathrm{S}$ to $\mathrm{G} 2$ phase whereas a higher concentration led to reversal of the $\mathrm{S}$ phase arrest. A similar activity was observed for HCT-116 human colon tumor cells, which indicates that cell cycle inhibition by resveratrol is independent of cyclooxygenase inhibition. Recent research, however, suggests that the chemopreventative activity of resveratrol at physiological doses is primarily linked to its ability to induce cell division cycle arrest and mitochondrial apoptosis, the latter through activation of pro-apoptotic proteins such as Bax, as well as independently of Bax. ${ }^{89}$ This ability is also independent of the p53 tumor suppressor activation. ${ }^{89}$

\section{Effect of wine on diabetes mellitus}

The prevalence of diabetes mellitus is escalating worldwide and its incidence is projected to increase from about 135 million in 1995 to 300 million in $2025 .{ }^{90}$ Type 2 diabetes mellitus, which accounts for more than $85 \%$ of all incidences of diabetes mellitus, is a disorder characterized by resistance to the effects of circulating insulin. This disorder leads to a substantial increase in risk of cardiovascular disease, which is the major cause of mortality, accounting for up to $80 \%$ of all deaths in individuals with type 2 diabetes mellitus; ${ }^{91-93}$ the ageadjusted relative risk of death due to cardiovascular disease is approximately three-fold higher than in the general population. Approximately $30 \%$ to $60 \%$ of diabetic patients have hypertension. ${ }^{94,95}$ In addition, patients with type 2 diabetes mellitus have coexistent lipid disorders characterized by increased blood triglycerides and reduced HDL-cholesterol, as well as hemostatic and fibrinolytic abnormalities. ${ }^{93}$

Apart from obesity and physical inactivity there are few well-established modifiable risk factors for type 2 diabetes mellitus. Recent evidence suggests, however, that alcohol consumption may be a potentially modifiable risk factor for type 2 diabetes mellitus and a J-shaped relationship has been observed between level of alcohol consumption and risk of developing diabetics in both men and women. ${ }^{96-98}$ The risk of developing type 2 diabetes mellitus was observed to be most reduced for women when their daily consumption was between $15.0 \mathrm{~g}$ to $29.9 \mathrm{~g}$ alcohol..$^{98}$ Indeed, as in the 
general population, there is also a decrease in cardiovascular risk with mild-to-moderate alcohol consumption in type 2 diabetics. ${ }^{99,100}$ For example, in males, the risk only increases when approximately $210 \mathrm{~g}$ alcohol are consumed per week, however, a similar increased risk has not necessarily been observed for wine consumers. ${ }^{101,102}$ A J-shaped relationship has also been observed between insulin sensitivity and level of alcohol consumption, where the moderate consumption of alcohol has been observed to improve insulin sensitivity, possibly by reducing the concentration of free fatty acids in blood. ${ }^{103,104}$ In turn, the improved insulin sensitivity lowers the concentration of insulin, glucose and triglycerides in the blood, and increases that of HDL, while LDL particles become less dense, less adherent and less easily oxidized. Altogether, this reduces the risk of developing type 2 diabetes mellitus, as well as improving control of blood glucose and reducing the risk of cardiovascular disease in type 2 diabetic. ${ }^{105,106}$ Following the consumption of $120 \mathrm{~mL}$ to $240 \mathrm{~mL}$ wine daily for 30 days fasting serum insulin concentration was also lowered. ${ }^{107}$

Patients with diabetes mellitus have other risk factors for cardiovascular disease such as a decreased total antioxidant capacity of plasma and concomitant increased LDL oxidation post-prandially. ${ }^{108,109}$ Ceriello and colleagues ${ }^{110}$ observed, however, that the consumption of red wine with food in type 2 diabetic patients decreased LDL oxidation post-prandially. ${ }^{111}$ Furthermore, the post-prandial hypoglycemia experienced in diabetes mellitus, which activates coagulation, ${ }^{12}$ was decreased by the consumption of red wine. The consumption of red wine by fasting type 2 diabetic patients, however, did not decrease either LDL oxidation or coagulation. Landrault and colleagues ${ }^{113}$ also investigated whether wine-derived phenolic compounds increased the total plasma antioxidant capacity in an insulin-deficient diabetic rat model, as well as affecting glycemia or blood sugar concentration, the biomarker of diabetes. Following the medium-term administration of both phenolic-enriched white wine and dealcoholized phenolicenriched white wine, the total plasma antioxidant capacity of the diabetic rats was increased to the level of nondiabetic rats and the level of glycemia reduced by $15 \%$ to $20 \%$. This suggests that moderate wine consumption may also attenuate the debilitating hyper- and hypoglycemic symptoms of diabetes.

Furthermore, increased inflammation via an increase in circulating pro-inflammatory cytokines has been observed in both diabetic and nondiabetic patients and to be involved in the pathogenesis of cardiovascular complications such as endothelial dysfunction after a myocardial infarction. ${ }^{114}$ Winederived phenolic compounds have anti-inflammatory actions including inhibition of reaction oxygen species in neutrophils, monocytes and macrophages. ${ }^{115,116}$ In subjects with diabetes, red wine consumption, taken with meals, significantly reduces oxidative stress and the circulating concentration of pro-inflammatory cytokines from lymphocytes and macrophages such as C-reactive protein, tissue necrosis factor-alpha and interleukin-6, as well as improving cardiac function after a myocardial infarction. ${ }^{117}$

\section{Effect of wine on metabolic syndrome}

Displipidemia in combination with hypertension and hyperglycemia often occur together in susceptible individuals, and is referred to as the 'metabolic syndrome'. ${ }^{118}$ The dislipidemia or blood lipid disturbance relates to being overweight or obese (BMI greater than $30 \mathrm{~kg} / \mathrm{m}^{2}$ ), especially in individuals who store their fat in the abdominal area. An excess of toxic free fatty acids in the blood stream may cause or contribute to the insulin sensitivity and impaired insulin function observed with this syndrome, which generally eventually develops into type 2 diabetes mellitus. Metabolic syndrome is considered as a multiplex risk factor for cardiovascular disease. ${ }^{119}$

The obese (BMI greater than $30 \mathrm{~kg} / \mathrm{m}^{2}$ ) and severely obese (BMI greater than $35 \mathrm{~kg} / \mathrm{m}^{2}$ ) are at increased risk of type 2 diabetes, cardiovascular morbidity and mortality. In a study of 486 severely obese subjects, consumers of alcohol showed a marked reduction in the prevalence of type 2 diabetes compared with non-consumers. ${ }^{120} \mathrm{~A} \mathrm{~J}$-shaped relationship was observed between both the amount and frequency of alcohol consumption and the plasma concentration of fasting triglyceride, fasting glucose, glycosylated hemoglobin A1c and insulin measurements. Consumers of less than $100 \mathrm{~g}$ of alcohol/week had more favorable insulin measures, with insulin sensitivity best in those consuming 20 to $100 \mathrm{~g}$ alcohol/week. Of the 276 alcohol consumers, 165 nominated wine as the alcoholic beverage most frequently consumed, and they were observed to have a significantly lower fasting insulin level and improved insulin sensitivity. In addition, when the subjects went on to have a laparoscopic adjustable gastric band placed to help them lose weight, those subjects consuming more than $100 \mathrm{~g}$ alcohol/week, especially wine, had significantly better weight loss $(50.4 \%$ of excess weight lost (EWL) at the end of the first year) than those with nil or negligible consumption (40.1\% EWL). Those consuming 20 to $100 \mathrm{~g} /$ week had an intermediate outcome ( $45.4 \% \mathrm{EWL})$.

An inverse association between wine consumption and metabolic syndrome was also observed in both 1138 nonobese and 395 obese female wine consumers compared with 
abstainers, although the amount of wine consumed was not considered. ${ }^{121}$ When amount of alcohol was considered in a similar dietary study of 4153 subjects (with a mean BMI of 25.8 and $25.3 \mathrm{~kg} / \mathrm{m}^{2}$ for men and women, respectively), moderate alcohol consumers (20 to $45 \mathrm{~g}$ alcohol/day) had a lower prevalence of metabolic syndrome and type 2 diabetes compared with abstainers, light consumers and heavy consumers, where wine was preferentially consumed by $29 \%$ of the subjects. ${ }^{122}$ In contrast to Dixon and colleagues, ${ }^{120}$ the amount of alcohol and wine consumption was related to body weight as observed in other studies. ${ }^{123}$ Data from the US National Heart, Lung and Blood Institute Family Heart Study suggest that there is actually a J-shaped relationship between the prevalence and risk of metabolic syndrome and alcohol consumption per se, ${ }^{124}$ associated with an increased HDL concentration and a lowered triglyceride concentration and improved insulin sensitivity. Such a J-shaped relationship has also been observed for wine consumption where the lowest prevalence was observed at 10 to $30 \mathrm{~g}$ alcohol/day as wine. ${ }^{125}$

\section{Potential mechanisms of action}

As an alteration has been observed in the relationship between the concentration of the amino acid homocysteine, and that of folate and vitamin B12, as people lose weight, ${ }^{126}$ the 464 severely obese patients were also studied for any relationship between both the amount and type of alcohol consumption and concentration of plasma homocysteine, an amino acid, during fasting. ${ }^{120}$ A higher plasma concentration of folate and vitamin B12 is needed to maintain the concentration of homocysteine as weight is lost. A J-shaped relationship was observed whereby light to moderate alcohol consumption up to $100 \mathrm{~g} /$ week was associated with a lower and more favorable plasma concentration of homocysteine compared with nonconsumers. The lower concentration of homocysteine in regular alcohol consumers was associated with a higher concentration of the micronutrient folate. Red wine consumers had a significantly lower mean fasting concentration of homocysteine compared with nonconsumers, beer and spirit consumers, and white wine consumers, even after controlling for sex, age, and body weight, and plasma concentration of folate and vitamin B12. The mechanisms for a beneficial effect of red wine consumption on the plasma concentration of homocysteine are unclear, and other studies have conversely suggested that above moderate alcohol consumption is associated with an increased plasma concentration of homocysteine. ${ }^{127,128}$ A high plasma concentration of homocysteine is also another risk factor for atherosclerosis, endothelial dysfunction and cardiovascular disease. ${ }^{129-131}$
It is now proposed that the development of the metabolic syndrome may be related to a deficiency in endothelial nitric oxide synthase (eNOS) given that eNOS knockout mice present a cluster of risk factors for cardiovascular disease comparable with those of metabolic syndrome, such as hypertension, insulin resistance and dyslipidemia. ${ }^{132}$ Human eNOS polymorphisms have since been associated with hypertension, insulin resistance and diabetes, with inflammation and oxidative stress markers and with albuminuria. ${ }^{133-136}$ As insulin resistance impairs endothelial function, diabetics experience impaired insulin-induced, nitric oxide-mediated vasodilation, which extended, may eventuate in hypertension. ${ }^{137-139}$

Wine consumption has been associated with improved endothelial function and vasodilation in animals and humans. ${ }^{140}$ For example, red grape juice, wine and dealcoholized red wine, as well as specific wine-derived phenolic compounds as catechin and quercetin, have been observed in animal, in vitro and in vivo to relax vascular endothelial smooth muscle, by inducing or up-regulating eNOS, thereby inducing the synthesis and release of nitric oxide from endothelial cells. ${ }^{141-147}$ Accordingly, the protective effects of moderate wine consumption may be attributed to the wine-derived phenolic compounds and their ability induce NO synthesis, in addition to modulating vascular tone by regulating other endothelial factors such as inducing the production of endothelium-derived hyperpolarizing factor, ${ }^{148}$ and inhibiting the expression of endothelin-1 (ET-1). ${ }^{149,150}$ ET-1 is a potent vasoconstrictor peptide and its overproduction is another risk factor for atherosclerosis.

\section{Effect of wine on cognitive function}

Over the last five years, evidence has accumulated which suggests that the J-shaped relationship could also be extended to a reduced risk of cognitive dysfunction. Cognitive function is defined as the intellectual or mental processes by which knowledge is acquired, including perception, reasoning, acts of creativity, problem-solving and possible intuition.

Cognitive dysfunction or impairment is associated with increased disability and an increased need for institutionalized care, especially in an aging population over 65 years of age. Dementia is a form of cognitive dysfunction whereby an individual loses the ability to think, remember and reason due to physical changes in the brain.

Prior to a study by Zuccala and colleagues, ${ }^{26}$ there was conflicting evidence on the relationship between alcohol consumption and cognitive function. ${ }^{25,151-157}$ Zuccala and colleagues ${ }^{26}$ analyzed the association between alcohol consumption and cognitive impairment in 15,807 hospitalized 
older patients who were enrolled in an Italian multicentre pharmacoepidemiology survey. The probability of cognitive impairment was reduced among male patients who reported an average daily alcohol consumption of $1 \mathrm{~L}$ or less of wine, as compared with abstainers, but the probability increased among heavier drinkers. Among women, only the lightest-drinking category $(<0.5 \mathrm{~L})$ showed a decreased probability of cognitive dysfunction when compared with abstainers, whereas heavier drinking was associated with an increased probability of cognitive impairment. The prevalence of alcohol abuse was similar among participants with cognitive impairment $(0.9 \%)$ and those with normal cognitive functioning (1\%). The results of this study indicated that $<40 \mathrm{~g}$ alcohol/day for women and $<80 \mathrm{~g}$ for men is associated with reduced probability of cognitive impairment as compared with abstinence, after adjusting for potential confounders. This nonlinear association persisted when cerebrovascular and Alzheimer's disease were considered separately. Such a nonlinear association might explain the conflicting results of previous studies regarding the relationship between alcohol consumption and cognitive functioning.

The observed gender difference in amount of alcohol consumption necessary for improved cognitive function, confirms that observed by Elias and colleagues, ${ }^{25}$ who showed that 'superior' cognitive performance was found with in the range of approximately 40 to $80 \mathrm{~g}$ /day for men but only approximately 20 to $40 \mathrm{~g} /$ day for women, compared to abstainers. Forty grams and $20 \mathrm{~g}$ alcohol/day for men and women, respectively, are at the upper end of the moderation range. ${ }^{21-24}$

Subsequent studies have also independently assessed the association between alcohol consumption and cognitive function and have affirmed the observations of Zuccala and colleagues $^{26}$ but have also provided more detailed data. ${ }^{158-162}$ For example, Reid and colleagues ${ }^{161}$ in a study of 760 US men aged 65 years or older showed that current light to moderate alcohol consumption which was considered as up to approximately $70 \mathrm{~g} /$ week, compared to abstinence, had better cognitive function. In particular, processing speed, which is the ability to perform tasks requiring rapid visual scanning and mental processing of information, was better even after adjusting for potential confounders such as education and occupation. In addition, the study assessed the effects of cumulative lifetime alcohol consumption on cognitive function and showed that the number of years of light to moderate alcohol consumption was strongly associated with better cognitive function. Results from a small survey study by McDougall and colleagues ${ }^{160}$ also suggested that men aged 65 years or older who drank moderately had significantly less depression, higher self-reported general health and higher cognitive function, flexibility and verbal memory.

Several studies had shown that the association between alcohol consumption and cognitive function is stronger for women than for men, which may simply reflect a gender difference in cognitive function or perhaps a misclassification of moderate alcohol consumers. Such a gender difference was not, however, observed by in a longitudinal study of 1624 Japanese American men and women aged over 65 years. ${ }^{163}$ Other studies which assessed women specifically, such as the US Nurses' Health Study, suggested that for women aged 71 to 80 years, up to $15 \mathrm{~g}$ alcohol/day did not impair cognitive function and actually improved it compared to abstinence, ${ }^{159}$ the women also had a decreased risk of cognitive impairment of approximately $20 \%$. No significant differences were observed in cognitive performance or risk between beer and wine consumers. Furthermore, a study of women aged 65-80 years, showed that women consuming any alcohol performed better on tests of verbal knowledge, fluency and memory, and figural memory, attention and working memory and motor speed compared to abstainers $(\mathrm{p}<0.05) .{ }^{164}$ After covariate adjustment, mean scores were higher among women reporting $\geq 10 \mathrm{~g}$ alcohol/day by $5.7 \%$ for verbal knowledge $(\mathrm{p}<0.001)$ and by $5.7 \%$ for phonemic fluency $(\mathrm{p}=0.004)$, compared to abstainers.

\section{Potential mechanisms of action}

The beneficial effects of alcohol on the risk of cardiovascular and cerebrovascular diseases, such as heart attacks and strokes, have been partly attributed to changes in lipid and hemostatic or blood flow factors. ${ }^{165}$ These changes include alcohol-induced increases in the concentration of high density lipoprotein-cholesterol and the thrombolyic proteins tissue type plasminogen activator activity and tissue type plasminogen activator antigen, and alcohol-induced reductions in fibrinogen, and clotting cofactors factor VII and von Willebrand factor. These changes are also associated with atherosclerosis which is the accumulation of atheromatous plaques containing cholesterol and lipids on the innermost layer of the walls of large and mediumsized arteries. As atherosclerosis has been associated with both Alzheimer's disease and vascular dementia, it had been suggested that any beneficial effect of alcohol on atherosclerosis could be expected to benefit these major subtypes of dementia by preserving brain vasculature, consequently resulting in better cognitive function. Wright and colleagues, ${ }^{162}$ however, showed that the appearance 
of plaque on the carotid artery which carries blood to the brain was not associated with alcohol consumption and alcohol-associated improvements in cognitive function. This suggests then that alcohol may impact cognition through a separate vascular or degenerative pathway. Among older persons without cerebrovascular disease, those who moderately consume alcohol have been shown to have fewer white-matter abnormalities and infarcts on magnetic resonance imaging than abstainers, ${ }^{166}$ where pronounced reductions in the risk of both vascular dementia and Alzheimer's disease have been shown among persons consuming 10 to $60 \mathrm{~g}$ alcohol/week. ${ }^{167}$

Indeed, there is also evidence which suggests that a light to moderate amount of alcohol may stimulate the release of acetylcholine in the hippocampus leading to improved cognitive function such that a light amount of alcohol in normal subjects appears to improve memory for events experienced before consumption where the impairment of memory performance by chronic and heavy alcohol consumption parallels the reduction of acetylcholine neurotransmission. ${ }^{168}$

\section{Effect of wine on Alzheimer's disease and dementia}

The immoderate or excessive consumption of alcoholic beverages is associated with an increased risk of dementia probably directly resulting from the neurotoxic effect of ethanol or indirectly from concomitant malnutrition/ nutritional deficiencies or trauma. ${ }^{169}$ The moderate consumption of alcoholic beverages, however, has been associated with comparatively better cognitive function in two studies: The Zutphen Elderly Study ${ }^{170}$ and the Honolulu Asia Aging Study. ${ }^{171}$ A third study, The Rotterdam Study, demonstrated that moderate alcohol consumption reduced the risk of vascular dementia in particular, and also that of Alzheimer's disease in individuals aged 55 years or older, ${ }^{172}$ which is supported by the results of other studies by Huangand colleagues ${ }^{173}$ and Mukamal and colleagues. ${ }^{167}$ Alzheimer's disease is a complex, late-onset disorder characterized by the loss of memory and multiple cognitive functions, which is associated with the presence of intracellular neurofibrillary tangles, extracellular amyloid- $\beta$ peptides, synaptic failure and mitochondrial dysfunction. ${ }^{174}$ In these prospective population-based studies, moderate consumption was defined as one to three drinks/ day. It has been suggested that ethanol may directly stimulate the release of acetylcholine in the hippocampus, which is associated with learning and memory. ${ }^{175} \mathrm{In}$ a rat model, a moderate concentration of alcohol $(0.8 \mathrm{~g} / \mathrm{kg})$ stimulated the release of acetylcholine while a higher concentration $(2.4 \mathrm{~g} / \mathrm{kg})$ inhibited its release. ${ }^{176}$

Four studies have further suggested that moderate wine consumption is associated with a lower risk of dementia and specifically Alzheimer's disease. ${ }^{176-181}$ In the prospective population-based study by Orgogozo and colleagues ${ }^{176}$ the sole source of alcohol was wine for $95 \%$ of consumers, which did not allow for beverage differentiation. In the Copenhagen City Heart Study (1991-1994) and in the Washington Heights InwoodColumbia Aging Project (1991-1996), however, only wine was associated with a lower risk or incidence. ${ }^{180,181}$ In the latter study, a lower risk was confined to wine consumers without the APOE-epsilon 4 allele, which is implicated in atherosclerosis, Alzheimer's disease, and impaired cognitive function, possibly influencing the increased deposition of amyloid- $\beta$ in the brain as it is less effective compared to other alleles at facilitating the proteolytic break-down of this peptide, both within and between cells. ${ }^{182}$ Amyloid- $\beta$ is a core component of the plaque or lesion found in the neocortex and hippocampus of diseased brains. Resveratrol, but not catechin or quercetin, decreased the level of intracellular amyloid- $\beta$ produced by different cell lines expressing the wild type of Swedish mutant amyloid- $\beta$ precursor protein $\left(\mathrm{APP}_{695}\right)$ by promoting its intracellular degradation. ${ }^{183}$ This mechanism was proteasome-dependent, that is, resveratrol appeared to activate the proteasome involved in the degradation of amyloid- $\beta$, as the resveratrol-induced decrease of amyloid- $\beta$ could be prevented by several selective proteasome inhibitors and by siRNA-directed silencing of the proteasome subunit $\beta 5 .^{183}$

Supplementation of diet with antioxidants such as $\alpha$-tocopherol may also improve cognitive function and slow functional deterioration. ${ }^{184}$

\section{Effect of wine on Parkinson's disease}

A potential role for wine in Parkinson's disease has been less well studied although it is the second most common neurodegenerative disorder after Alzheimer's disease. It is has been linked to increased levels of oxidative and nitrosative stress, ${ }^{185,186}$ and is characterized by a progressive loss of dopaminergic neurons in the substantia nigra pars compacta region of the brain and the appearance of Lewy bodies and neurites which comprise insoluble amyloid-like fibrils that contain the protein alpha-synuclein. Oxidative stress apparently promotes the aggregation of alpha-synuclein. ${ }^{187}$ A reduced risk of Parkinson's disease has been observed for 
moderate alcohol consumers ${ }^{188-190}$ which did not distinguish between alcoholic beverages. Such a reduced risk has, however, been specifically shown for wine consumers where an inverse relationship between amount of wine consumed and risk was observed; the lowest risk was observed for wine consumers of approximately 140 to $420 \mathrm{~g}$ alcohol/week. ${ }^{191}$ Wine-derived phenolic compounds such as catechin and epi-catechin have recently been observed in vitro to inhibit the formation of alpha-synuclein fibrils, and to destabilize preformed fibrils. ${ }^{192}$

\section{Conclusions}

The protective effect of moderate wine consumption against cancer, diabetes, metabolic syndrome, cognitive dysfunction, including dementia and Alzheimer's disease, and Parkinson's disease has been consistently observed over the past five years. Indeed, there is sufficient epidemiological evidence and plausible biological mechanisms to support the J-shaped relationship between moderate wine consumption and risk of cardiovascular disease that can be extended to cancer and to other degenerative diseases that are often inter-related. ${ }^{193-195}$ Thus, while excessive wine consumption should be avoided, it would appear safe and reasonable to recommend the continuation of light to moderate wine consumption in those already imbibing. A high level of risk factors for cancer and any degenerative disease, however, can mitigate any protective effects of moderate wine consumption. In addition, the effects of the excessive consumption of wine may be additive to any other risk factors for disease, increasing the risk by two to three-times.

\section{Disclosure}

The author reports no conflict of interest in this work.

\section{References}

1. Ames BN, Gold LS, Willett WC. The causes and prevention of cancer. Proc Natl Acad Sci U S A. 1995;92(12):5258-5265.

2. Smith MA, Perry G, Richey PL, et al. Oxidative damage in Alzheimer's. Nature. 1996;382(6587):120-121.

3. Commenges D, Scotet V, Renaud S, Jacqmin-Gadda H, BarbergerGateau P, Dartigues JF. Intake of flavonoids and risk of dementia. Eur J Epidemiol. 2000;16(4):357-363.

4. Olanow CW. The pathogenesis of cell death in Parkinson's disease 2007. Mov Disord. 2007;22(Suppl 17):S335-S442.

5. Kelner KL, Marx J. Patterns of aging. Science. 1996;273(5271):41.

6. Boffetta P, Garfinkel L. Alcohol drinking and mortality among men enrolled in an American Cancer Society prospective study. Epidemiology. 1990;1:342-348.

7. Marmot M, Brunner E. Alcohol and cardiovascular disease: the status of the J-shaped curve, Br Med J. 1991;303:565-568.

8. Thun MJ, Peto R, Lopez A, et al. Alcohol consumption and mortality among middle-aged and elderly US adults. $N$ Eng $J$ Med. 1997;337:1705-1714.
9. Kono S, Shinshi K, Ikeda N, Yanai F, Imanishi K. Prevalence of gallstone disease in relation to smoking, alcohol use, obesity and glucose tolerance: a study of self defence officials in Japan. Am J Epidemiol. 1992;36:787-791.

10. Holbrook TL, Barrett-Connor E. A prospective study of alcohol consumption and bone mineral density. Br Med J. 1993;306:1506-1509.

11. Lipton R. The effect of moderate alcohol consumption on the relationship between stress and depression. Am J Public Health. 1994;84:1913-1917.

12. Voigt LF, Kepsell TD, Nelson JL, Dugowson CE, Daling JR. Smoking, obesity, alcohol consumption and the risk of rheumatoid arthritis. Epidemiology. 1994;5:525-528.

13. La Vecchia C, Decarli A, Franceschi S, Ferraroni M, Pagano R. Prevalence of chronic diseases in alcohol abstainers. Epidemiology. 1995; 6:436-438.

14. Rimm EB, Chan J, Stampfer MJ, Colditz GA, Willett WC. Prospective study of cigarette smoking, alcohol use and the risk of diabetes in man. Br Med J. 1995;310:555-559.

15. Weisse ME, Eberly B, Person DA. Wine as a digestive aid: comparative antimicrobial effects of bismuth salicylate and red and white wine. Br Med J. 1995;311:1657-1660.

16. Brenner H, Rotherbacher D, Bode G, Adler G. Relation of smoking and alcohol and coffee consumption to active Heliobacter pylori infection: cross sectional study. Br Med J. 1997;315:1489-1492.

17. Obisesan TO, Hirsh R, Kosoko O, Carlson L, Parrott M. Moderate wine consumption is associated with decreased odds of developing agerelated macular degeneration in NHANES-1. J Am Geriatr Soc. 1998; $46: 1-7$.

18. Renaud SC, Gueguen R, Schenker J, d'Houtaud A. Alcohol and mortality in middle-aged men from eastern France. Epidemiology. 1998;9:184-188.

19. Roche A. Patterns, paradoxes and ambiguities of consumption. Perth, Australia: Second International Conference on Drinking Patterns and Their Consequences; February 1-5, 1998.

20. Heath DB. Alcohol and pleasure: a health perspective. In: Peele S and Grant M, editors. Alcohol and pleasure: A health perspective, Philadelphia, PA: Brunner/Mazel; 1999; p. 61-72.

21. Jackson R, Scragg R, Beaglehole R. Does recent alcohol consumption reduce the risk of acute myocardial infarction and coronary death in regular drinkers? Am J Epidemiol. 1992;136(7):819-824.

22. Palomaki H, Kaste M. Regular light-to-moderate intake of alcohol and the risk of ischemic stroke. Is there a beneficial effect? Stroke. 1993;24(12): 1828-1832.

23. Stockley CS. Wine in moderation: how could and should recent in vitro and in vivo data be interpreted? Drug Alc Rev. 1998;17:365-376.

24. Klatsky AL. Drink to your health? Scientific American. 2003;288(2):74-81.

25. Elias PK, Elias MF, D'Agostino RB, Silbershatz H, Wolf PA. Alcohol consumption and cognitive performance in the Framingham Heart Study. Am J Epidemiol. 1999;150:580-589.

26. Zuccala G, Onder G, Pedone C, et al. Gruppo Italiano di Farmacoepidemiologia nell'Anziano Investigators. Dose-related impact of alcohol consumption on cognitive function in advanced age: results of a multicenter survey. Alcohol Clin Exp Res. 2001;25(12):1743-1748.

27. Stockley CS. Recommendations on alcohol consumption: an international perspective. Contemp Drug Prob. 2008;34:681-711.

28. Corrao G, Bagnardi V, Zambon A, La Vecchia C. A meta-analysis of alcohol consumption and the risk of 15 diseases. Prevent Med. 2004;38(5):613-619.

29. Manach C, Donovan JL. Pharmacokinetics and metabolism of dietary flavonoids in humans. Free Radic Res. 2004;38(8):771-785.

30. Kroon PA, Clifford MN, Crozier A, et al. How should we assess the effects of exposure to dietary polyphenols in vitro? Am J Clin Nutr. 2004;80(1):15-21.

31. International Agency for Research on Cancer. Alcohol drinking. IARC monographs on the evaluation of carcinogenic risks to humans. Volume 44. Lyon: IARC, 1988 [Last updated 01/21/98].

32. International Agency for Research on Cancer. IARC GLOBOCAN 2002 database. 
33. Longnecker MP, Orza MJ, Adams ME, Vioque J, Chalmers TC. A meta-analysis of alcoholic beverage consumption in relation to risk of colorectal cancer. Cancer Causes Control. 1990;1:59-68.

34. Lewis S, Campbell S, Proudfoot E, Weston A, Cotter T, Bishop J. Alcohol as a Cause of Cancer. Sydney, Australia: Cancer Institute NSW; 2008.

35. Longnecker MP. Alcohol consumption and risk of cancer in humans: an overview. Alcohol. 1995;12(2):87-96.

36. Williams RR, Hor JW. Association of cancer sites with tobacco and alcohol consumption and socioeconomic status of patients interview study from the Third National Cancer Survey. J Natl Cancer Inst. 1977;58:525-547.

37. Macfarlane GJ, Macfarlane TV, Lowenfels AB. The influence of alcohol consumption on worldwide trends in mortality from upper aerodigestive tract cancers in men. $J$ Epidemiol Community Health. 1996;50(6):636-639.

38. Launoy G, Milan CH, Faivre J, Pienkowski P, Milan CI, Gignoux M. Alcohol, tobacco and oesophageal cancer: effects of the duration of consumption, mean intake and current and former consumption. $\mathrm{Br} J$ Cancer. 1997;75(9):1389-1396.

39. Gapstur SM, Potter JD, Sellers TA, Folsom AR. Increased risk of breast cancer with alcohol consumption in postmenopausal women. Am J Epidemiol. 1992;136:1221-1231.

40. Rosenberg L, Metzger LS, Palmer JR. Alcohol consumption and risk of breast cancer: a review of the epidemiological evidence. Epidemiol Rev. 1993;15:133-144.

41. Longnecker MP. Alcoholic beverage consumption in relation to risk of breast cancer: meta-analysis and review. Cancer Causes Control. 1994;5:73-82.

42. Van den Brandt PA, Goldbolm A, van't Veer P. Alcohol and breast cancer: results from the Netherlands Cohort Study. Am J Epidemiol. 1995;141:907-915.

43. Swanson CA, Coates RJ, Malone KE, et al. Alcohol consumption and breast cancer risk among women under age 45 years. Epidemiology. 1997;8:231-237.

44. Vachon CM, Cerhan JR, Vierkant RA, Sellers TA. Investigation of an interaction of alcohol intake and family history on breast cancer risk in the Minnesota Breast Cancer Family Study. Cancer. 2001;92(2):240-248.

45. Horn-Ross PL, Canchola AJ, West DW, et al. Patterns of alcohol consumption and breast cancer risk in the California Teachers Study cohort. Cancer Epidemiol Biomarkers Prev. 2004;13(3):405-411.

46. Li Y, Baer D, Friedman GD, Udaltsova N, Shim V, Klatsky AL. Wine, liquor, beer and risk of breast cancer in a large population. Eur J Cancer. 2009;45(5):843-850.

47. Newcomb PA, Nichols HB, Beasley JM, et al. No difference between red wine or white wine consumption and breast cancer risk. Cancer Epidemiol Biomarkers Prev. 2009;18(3):1007-1010.

48. Smith-Warner SA, Spiegelman D, Yaun SS, et al. Alcohol and breast cancer in women: a pooled analysis of cohort studies. JAMA. 1998;279(7):535-540.

49. Singletary KW, Gapstur SM. Alcohol and breast cancer: review of epidemiological and experimental evidence and potential mechanisms. JAMA. 2001;286:2143-2151.

50. Mørch LS, Johansen D, Thygesen LC, et al. Alcohol drinking, consumption patterns and breast cancer among Danish nurses: a cohort study. Eur J Public Health. 2007;17(6):624-629.

51. Kuper H, Ye W, Weiderpass E, et al. Alcohol and breast cancer risk: the alcoholism paradox. Br J Cancer. 2000;83(7):949-951.

52. Gronbaek M, Becker U, Johansen D, et al. Type of alcohol consumed and mortality from all causes, coronary heart disease and cancer. Ann Intern Med. 2000;133:411-419.

53. Briggs NC, Levine RS, Bobo LD, Haliburton WP, Brann EA, Hennekens $\mathrm{CH}$. Wine drinking and risk of non-Hodgkin's lymphoma among men in the United States: a population-based case-control study. Am J Epidemiol. 2002;156(5):454-462.

54. Gronbaek M, Becker U, Johansen D, Tonnesen H, Jensen G, Sorensen TI. Population based cohort study of the association between alcohol intake and cancer of the upper digestive tract. $\mathrm{Br}$ Med J. 1998;317(7162):844-847.
55. Prescott E, Gronbaek M, Becker U, Sorensen TI. Alcohol intake and the risk of lung cancer: influence of type of alcoholic beverage. Am J Epidemiol. 1999;149(5):463-470.

56. Barstad B, Sørensen TI, Tjønneland A, et al. Intake of wine, beer and spirits and risk of gastric cancer. Eur J Cancer Prev. 2005;14(3):239-243.

57. Chao C. Associations between beer, wine, and liquor consumption and lung cancer risk: a meta-analysis. Cancer Epidemiol Biomarkers Prev. 2007;16(11):2436-2447.

58. Pedersen A, Johansen C, Grønbaek M. Relations between amount and type of alcohol and colon and rectal cancer in a Danish population based cohort study. Gut. 2003;52(6):861-867.

59. Sutcliffe S, Giovannucci E, Leitzmann MF, et al. A prospective cohort study of red wine consumption and risk of prostate cancer. Int J Cancer. 2007;120(7):1529-1535.

60. Ames B, Shigenaga MK, Hagen TM. Oxidants, antioxidants, and the degenerative diseases of aging. Proc Natl Acad Sci U S A. 1993;90:7915-7922.

61. Fenech M, Crott J, Turner J, Brown S. Necrosis, apoptosis, cytostasis and DNA damage in human lymphocytes measured simultaneously within the cytokinesis-block micronucleus assay: description of the method and results for hydrogen peroxide. Mutagenesis. 1999a; $14: 605-612$.

62. Fenech M, Holland N, Chang WP, Zeiger E, Bonassi S. The HUman MicroNucleus Project-An international collaborative study on the use of the micronucleus technique for measuring DNA damage in humans. Mutat Res. 1999b;428:271-283.

63. De Flora S, Izzotti A, Walsh D, Degan P, Petrilli GL, Lewtas J. Molecular epidemiology of atherosclerosis. FASEB J. 1997;11(12):1021-1031.

64. Andreassi MG, Botto N, Colombo MG, Biagini A, Clerici A. Genetic instability and atherosclerosis: can somatic mutations account for the development of cardiovascular disease? Env Mol Mutagenesis. 2000;35:265-269.

65. Izzotti A, Camoirano A, Cartiglia C, Tampa E, De Flora S. Formation of DNA adducts in the aorta of smoke-exposed rats, and modulation by chemopreventative agents. Mutat Res. 2001;494:97-106.

66. Botto N, Rizza A, Colombo MG, et al. Evidence for DNA damage in patients with coronary artery disease. Mutation Res. 2001;493:23-30.

67. Fenech M, Stockley C, Aitken C. Moderate wine consumption protects against hydrogen peroxide-induced DNA damage. Mutagenesis. 1997;12:289-296.

68. Leighton F, Cuevas A, Guasch V, et al. Plasma polyphenols and antioxidants, oxidative DNA damage and endothelial function in a diet and wine intervention study in humans. Drugs Exp Clin Res. 1999;25(2-3):133-141.

69. Greenrod W, Fenech M. The principal phenolic and alcoholic components of wine protect human lymphocytes against hydrogen peroxideand ionising radiation-induced DNA damage in vitro. Mutagenesis. 2003;18(2):119-126.

70. Fenech $\mathrm{M}$. The cytokinesis-block micronucleus technique: a detailed description of the method and its application to genotoxicity studies in human populations. Mutat Res. 1993;285:35-44.

71. Greenrod W, Stockley CS, Burcham P, Abbey M, Fenech M. Moderate acute intake of de-alcoholised red wine, but not alcohol, is protective against radiation-induced DNA damage ex vivo - results of a comparative in vivo intervention study in Mutat Res. 2005;591(1-2):290-301.

72. Casalini C, Lodovici M, Briani C, et al. Effect of complex polyphenols and tannins from red wine (WCPT) on chemically induced oxidative DNA damage in the rat. Eur J Nutr. 1999;38(4):190-195.

73. Dihal AA, de Boer VC, van der Woude H, et al. Quercetin, but not its glycosidated conjugate rutin, inhibits azoxymethane-induced colorectal carcinogenesis in F344 rats. J Nutr. 2006;136(11):2862-2867.

74. Franke AA, Custer LJ, Cooney RV, Tanaka Y, Xu M, Dashwood RH. Inhibition of colonic aberrant crypt formation by the dietary flavonoids (+)-catechin and hesperidin. Adv Exp Med Biol. 2002;505:123-133.

75. Tsan MF, White JE, Maheshwari JG, Bremner TA, Sacco J. Resveratrol induces Fas signalling-independent apoptosis in THP-1 human monocytic leukaemia cells. Br J Haematol. 2000;109(2):405-412. 
76. Ahmad N, Adhami VM, Afaq F, Feyes DK, Mukhtar H. Resveratrol causes WAF-1/p21-mediated G(1)-phase arrest of cell cycle and induction of apoptosis in human epidermoid carcinoma A431 cells. Clin Cancer Res. 2001;7(5):1466-1473.

77. Stivala LA, Savio M, Carafoli F, et al. Specific structural determinants are responsible for the antioxidant and the cell cycle effects of resveratrol. J Biol Chem. 2001;276(25):22586-22594.

78. Elattar TM, Virji AS. The effect of red wine and its components on growth and proliferation of human oral squamous carcinoma cells. Anticancer Res. 1999a;19(6B):5407-5414.

79. Hsieh TC, Burfeind $\mathrm{P}$, Laud K, et al. Cell cycle effects and control of gene expression by resveratrol in human breast carcinoma cell lines with different metastatic potentials. Int J Oncol. 1999a;15(2):245-252.

80. Hsieh TC, Juan G, Darzynkiewicz Z, Wu JM. Resveratrol increases nitric oxide synthase, $\mathrm{p} 21$ (WAF1/CIP1), and suppresses cultured bovine pulmonary artery endothelial cell proliferation by perturbing progression through S and G2. Cancer Res. 1999b;59(11):2596-2601.

81. Hsieh TC, Wu JM. Differential effects on growth, cell cycle arrest, and induction of apoptosis by resveratrol in human prostate cancer cell lines. Exp Cell Res. 1999c;249(1):109-115.

82. Damianaki A, Bakogeorgou E, Kampa M, et al. Potent inhibitory action of red wine polyphenols on human breast cancer cells. J Cell Biochem. 2000;78(3):429-441.

83. Kampa M, Hatzoglou A, Notas G, et al. Wine antioxidant polyphenols inhibit the proliferation of human prostate cancer cell lines. Nutr Cancer. 2000;37(2):223-233.

84. Mutoh M, Takahashi M, Fukuda K, et al. Suppression by flavonoids of cyclooxygenase- 2 promoter-dependent transcriptional activity in colon cancer cells: structure-activity relationship. Jpn J Cancer Res. 2000;91(7):686-691.

85. Latruffe N, Delmas D, Jannin B, Malki MC, Passilly-Degrace P, Berlot JP. Molecular analysis on the chemopreventive properties of resveratrol, a plant polyphenol microcomponent. Int J Mol Med. 2002;10(6):755-760.

86. Elattar TM, Virji AS. Modulating effect of resveratrol and quercetin on oral cancer cell growth and proliferation. Anticancer Drugs. 1999b;10(2):187-193.

87. Schneider Y, Duranton B, Gosse F, Schleiffer R, Seiler N, Raul F. Resveratrol inhibits intestinal tumorigenesis and modulates hostdefense-related gene expression in an animal model of human familial adenomatous polyposis. Nutr Cancer. 2001;39(1):102-107.

88. Wolter F, Akoglu B, Clausnitzer A, Stein J. Downregulation of the cyclin D1/Cdk4 complex occurs during resveratrol-induced cell cycle arrest in colon cancer cell lines. J Nutr. 2001;131(8):2197-2203.

89. Pohland T, Wagner S, Mahyar-Roemer M, Roemer K. Bax and Bak are the critical complementary effectors of colorectal cancer cell apoptosis by chemopreventive resveratrol. Anticancer Drugs. 2006;17(4):471-478.

90. AusDiab Steering Committee. Diabetes and associated disorders in Australia. The accelerating epidemic. 2001 Report. Melbourne, Australia: International Diabetes Institute; 2001.

91. Feener EP, King GL. Endothelial dysfunction in diabetes mellitus: role in cardiovascular disease. Heart Fail Monit. 2001;1(3):74-82.

92. Gu W, Pagel PS, Warltier DC, Kersten JR. Modifying cardiovascular risk in diabetes mellitus. Anesthesiology. 2003;98(3):774-849.

93. Mooradian AD. Cardiovascular disease in type 2 diabetes mellitus: current management guidelines. Arch Intern Med. 2003;163(1):33-40.

94. Nilsson PM, Gudbjornsdottir S, Eliasson B, Cederholm J. Hypertension in diabetes: trends in clinical control in repeated large-scale national surveys from Sweden. J Hum Hypertens. 2003;17(1):37-44.

95. Vijan S, Hayward RA. Treatment of hypertension in type 2 diabetes mellitus: blood pressure goals, choice of agents, and setting priorities in diabetes care. Ann Intern Med. 2003;138(7):593-602.

96. de Vegt F, Dekker JM, Groeneveld WJ, et al. Moderate alcohol consumption is associated with lower risk for incident diabetes and mortality: the Hoorn Study. Diabetes Res Clin Pract. 2002;57(1):53-56.

97. Wannamethee SG, Shaper AG, Perry IJ, Alberti KG. Alcohol consumption and the incidence of type II diabetes. J Epidemiol Community Health. 2002;56(7):542-548.
98. Wannamethee SG, Camargo CA Jr, Manson JE, Willett WC, Rimm EB. Alcohol drinking patterns and risk of type 2 diabetes mellitus among younger women. Arch Intern Med. 2003;163:1329-1336.

99. Ajani UA, Gaziano JM, Lotufo PA, et al. Alcohol consumption and risk of coronary heart disease by diabetes status. Circulation. 2000b;102:500-505.

100. Hu FB, Manson JE, Stampfer MJ, et al. Diet, lifestyle, and the risk of type 2 diabetes mellitus in women. $N$ Engl J Med. 2001;345:790-797.

101. Carlsson S, Hammar N, Efendic S, Persson PG, Ostenson CG, Grill V. Alcohol consumption, Type 2 diabetes mellitus and impaired glucose tolerance in middle-aged Swedish men. Diabet Med. 2000;17(11): 776-778.

102. Kao WH, Puddey IB, Boland LL, Watson RL, Brancati FL. Alcohol consumption and the risk of type 2 diabetes mellitus: atherosclerosis risk in communities study. Am J Epidemiol. 2001;154(8):748-757.

103. Avogaro A, Watanabe RM, Gottardo L, de Kreutzenberg S, Tiengo A, Pacini G. Glucose tolerance during moderate alcohol intake: insights on insulin action from glucose/lactate dynamics. J Clin Endocrinol Metab. 2002;87:1233-1238.

104. Koppes LL, Dekker JM, Hendriks HF, Bouter LM, Heine RJ. Moderate alcohol consumption lowers the risk of type 2 diabetes: a meta-analysis of prospective observational studies. Diabetes Care. 2005;28:719-725.

105. Ajani UA, Hennekens CH, Spelsberg A, Manson JE. Alcohol consumption and risk of type 2 diabetes mellitus among US male physicians. Arch Intern Med. 2000a;160:1025-1030.

106. Solomon CG, Hu FB, Stampfer MJ, et al. Moderate alcohol consumption and risk of coronary heart disease among women with type 2 diabetes mellitus. Circulation. 2000;102:494-499.

107. Bantle AE, Thomas W, Bantle JP. Metabolic effects of alcohol in the form of wine in persons with type 2 diabetes mellitus. Metabolism. 2008;57(2):241-245.

108. Ceriello A, Bortolotti N, Motz E, et al. Meal-induced oxidative stress and low-density lipoprotein oxidation in diabetes: the possible role of hyperglycemia. Metabolism. 1999a;48(12):1503-1508.

109. Diwadkar VA, Anderson JW, Bridges SR, Gowri MS, Oelgten PR Postprandial low-density lipoproteins in type 2 diabetes are oxidized more extensively than fasting diabetes and control samples. Proc Soc Exp Biol Med. 1999;222(2):178-184.

110. Ceriello A, Bortolotti N, Motz E, et al. Red wine protects diabetic patients from meal-induced oxidative stress and thrombosis activation: a pleasant approach to the prevention of cardiovascular disease in diabetes. Eur J Clin Invest. 2001;31(4):322-328.

111. Ceriello A, Bortolotti N, Motz E, et al. Meal-generated oxidative stress in diabetes. The protective effect of red wine. Diabetes Care. 1999b;22(12):2084-2085.

112. Ceriello A, Taboga C, Tonutti L, et al. Post-meal coagulation activation in diabetes mellitus: the effect of acarbose. Diabetologia. 1996;39:469-473.

113. Landrault N, Poucheret P, Krosniak M, et al. Effect of a polyphenolcenriched Chardonnay white wine in diabetic rats. In: Meeting the consumer challenge. Proceedings of the 26th World Congress and 81st General Assembly of the Office International de al Vigne et du Vin, Adelaide, Australia. 11-17 October 2001. p. 304-312.

114. Nyström T, Nygren A, Sjöholm A. Increased levels of tumour necrosis factor-alpha (TNF-alpha) in patients with Type II diabetes mellitus after myocardial infarction are related to endothelial dysfunction. Clin Sci (Lond). 2006;110(6):673-681.

115. Martinez J, Moreno JJ. Effect of resveratrol, a natural polyphenolic compound, on reactive oxygen species and prostaglandin production. Biochem Pharmacol. 2000;59(7):865-870.

116. Feng YH, Zou JP, Li XY. Effects of resveratrol and ethanol on production of pro-inflammatory factors from endotoxin activated murine macrophages. Acta Pharmacol Sin. 2002;23(11):1002-1006.

117. Marfella R, Cacciapuoti F, Siniscalchi M, et al. Effect of moderate red wine intake on cardiac prognosis after recent acute myocardial infarction of subjects with Type 2 diabetes mellitus. Diabet Med. 2006;23(9):974-981. 
118. Reaven GM. Role of insulin resistance in human disease (syndrome X): an expanded definition. Annu Rev Med. 1993;44:121-131.

119. Grundy SM, Brewer HB Jr, Cleeman JI, Smith SC Jr, Lenfant C; American Heart Association; National Heart, Lung, and Blood Institute. Definition of metabolic syndrome: Report of the National Heart, Lung, and Blood Institute/American Heart Association conference on scientific issues related to definition. Circulation. 2004;109(3):433-438.

120. Dixon JB, Dixon ME, O'Brien PE. Reduced plasma homocysteine in obese red wine consumers: a potential contributor to reduced cardiovascular risk status. Eur J Clin Nutr. 2002;56(7):608-614.

121. Sonnenberg L, Pencina M, Kimokoti R, et al. Dietary patterns and the metabolic syndrome in obese and non-obese Framingham women. Obes Res. 2005;13:153-162.

122. Athyros VG, Liberopoulos EN, Mikhailidis DP, et al. Association of drinking pattern and alcohol beverage type with the prevalence of metabolic syndrome, diabetes, coronary heart disease, stroke, and peripheral arterial disease in a Mediterranean cohort. Angiology. 2008;58(6):689-697.

123. Vadstrup ES, Petersen L, Sørensen TI, Grønbaek M. Waist circumference in relation to history of amount and type of alcohol: results from the Copenhagen City Heart Study. Int J Obes Relat Metab Disord. 2003;27(2):238-246.

124. Djousse L, Arneff DK, Eckfeldt JH, Province MA, Singer MR, Ellison RC. Alcohol consumption and the metabolic syndrome: does the type of beverage matter? Obes Res. 2004;12:1375-1385.

125. Rosell M, De Faire U, Hellénius ML. Low prevalence of the metabolic syndrome in wine drinkers-is it the alcohol beverage or the lifestyle? Eur J Clin Nutr. 2003;57(2):227-234.

126. Dixon JB, Dixon ME, O’Brien PE. Elevated homocysteine levels with weight loss after Lap-Band(R) surgery: higher folate and vitamin $\mathrm{B}(12)$ levels required to maintain homocysteine level. Int JObes Relat Metab Disord. 2001;25:219-227.

127. Cravo ML, Gloria LM, Selhub J, et al. Hyperhomocysteinemia in chronic alcoholism: correlation with folate, vitamin B-12, and vitamin B-6 status. Am J Clin Nutr. 1996;63(2):220-224.

128. Bleich S, Bleich K, Kropp S, et al. Moderate alcohol consumption in social drinkers raises plasma homocysteine levels: a contradiction to the French Paradox? Alcohol Alcohol. 2001;36:189-192.

129. Nygard O, Nordrehaug JE, Refsum H, Ueland PM, Farstad M, Vollset SE. Plasma homocysteine levels and mortality in patients with coronary artery disease. N Engl J Med. 1997;337(4):230-236.

130. Bellamy M, McDowell I, Ramsay M, et al. Hyperhomocysteinemia after oral methionine load acutely Impairs endothelial function in healthy adults. Circulation. 1998;98(18):1848-1852.

131. Welsh G, Loscalzo J. Mechanisms of disease: Homocysteine and Atherothrombosis. N Engl J Med. 1998;338(15):1042-1050.

132. Cook S, Huglin O, Eglim, et al. Clustering of cardiovascular risk factors mimicking the human metabolic syndrome in eNOS null mice. Swiss Med Wkly. 2003;1339(25-26):360-363.

133. Monti LD, Barlassina C, Citterio L, et al. Endothelial nitric oxide synthase polymorphisms are associated with type 2 diabetes and the insulin resistance syndrome. Diabetes. 2003;52(5):1270-1275.

134. Fernandez ML, Ruiz R, Gonzalez MA, et al. Association of NOS3 gene with metabolic syndrome in hypertensive patients. Thromb Haemost. 2004;92(2):413-418.

135. Chrysohoou C, Panagiotakos DB, Pitsavos C, et al. Evidence for association between endothelial nitric oxide synthase gene polymorphism (G894T) and inflammatory markers: the ATTICA study. Am Heart J. 2004;148(4):733-738.

136. Liu Y, Burdon KP, Langefeld CD, et al. T-786C polymorphism of the endothelial nitric oxide synthase gene is associated with albuminuria in the diabetes heart study. J Am Soc Nephrol. 2005;16(4):1085-1090.

137. Steinberg HO, Tarshoby M, Monestel R, et al. Elevated circulating free fatty acid levels impair endothelium-dependent vasodilation. J Clin Invest. 1997;100(5):1230-1239.

138. Steinberg HO, Paradisi G, Hook G, Crowder K, Cronin J, Baron AD. Free fatty acid elevation impairs insulin-mediated vasodilation and nitric oxide production. Diabetes. 2000;49(7):1231-1238.
139. Lynn MA, Rupnow HL, Kleinhenz DJ, Kanner WA, Dudley SC, Hart CM. Fatty acids differentially modulate insulin-stimulated endothelial nitric oxide production by an Akt-independent pathway. J Investig Med. 2004;52(2):129-136.

140. Cuevas AM, Guasch V, Castillo O, et al. A high-fat diet induces and red wine counteracts endothelial dysfunction in human volunteers. Lipids. 2000;35:143-148.

141. Stoclet JC, Kleschyov A, Andriambeloson E, Diebolt M, Andriantsitohaina R. Endothelial no release caused by red wine polyphenols. J Physiol Pharmacol. 1999;50(4):535-540.

142. Diebolt M, Bucher B, Andriantsitohaina R. Wine polyphenols decrease blood pressure, improve NO vasodilatation, and induce gene expression. Hypertension. 2001;38(2):159-165.

143. Benito S, Lopez D, Sáiz MP, et al. A flavonoid-rich diet increases nitric oxide production in rat aorta. Br J Pharmacol. 2002;135(4): 910-916.

144. Leikert JF, Rathel TR, Wohlfart P, Cheynier V, Vollmar AM, Dirsch VM. Red wine polyphenols enhance endothelial nitric oxide synthase expression and subsequent nitric oxide release from endothelial cells. Circulation. 2002;106(13):1614-1617.

145. Wallerath T, Deckert G, Ternes T, et al. Resveratrol, a polyphenolic phytoalexin present in red wine, enhances expression and activity of endothelial nitric oxide synthase. Circulation. 2002;106(13):1652-1658.

146. Wallerath T, Poleo D, Li HG, Forstermann U. Red wine increases the expression of human endothelial nitric oxide synthase-a mechanism that may contribute to its beneficial cardiovascular effects. $\mathrm{J}$ Am Coll Cardiol. 2003;41(3):471-478.

147. Hollenberg NK. Red wine polyphenols enhance endothelial nitric oxide synthase expression and subsequent nitric oxide release from endothelial cells. Curr Hypertens Rep. 2003;5(4):287-288.

148. Ndiaye M, Chataigneau T, Chataigneau M, Schini-Kerth VB. Red wine polyphenols induce EDHF-mediated relaxations in porcine coronary arteries through the redox-sensitive activation of the PI3-kinase/Akt pathway. Br J Pharmacol. 2004;142(7):1131-1136.

149. Khan NQ, Lees DM, Douthwaite JA, Carrier MJ, Corder R. Comparison of red wine extract and polyphenol constituents on endothelin-1 synthesis by cultured endothelial cells. Clin Sci (London). 2002;103(Suppl 48):72S-75S.

150. Zou JG, Wang ZR, Huang YZ, Cao KJ, Wu JM. Effect of red wine and wine polyphenol resveratrol on endothelial function in hypercholesterolemic rabbits. Int J Mol Med. 2003;11(3):317-320.

151 Cervilla JA, Prince M, Mann A. Smoking, drinking, and incident cognitive impairment: a cohort community based study included in the Gospel Oak project. J Neurol Neurosurg Psychiatry. 2000;68:622-626.

152. Dent OF, Sulway MR, Broe GA, et al. Alcohol consumption and cognitive performance in a random sample of Australian soldiers who served in the second world war. Br Med J. 1997;314:1655-1657.

153. Dufouil C, Ducimetiere P, Alperovitch A. Sex differences in the association between alcohol consumption and cognitive performance. Am J Epidemiol. 1997;146:405-412.

154. Harwood DG, Barker WW, Loewenstein DA, et al. A cross-ethnic analysis of risk factors for $\mathrm{AD}$ in white Hispanics and white nonHispanics. Neurology. 1999;52:551-556.

155. Hendrie HC, Gao S, Hall KS, Hui SL, Unverzagt FW. The relationship between alcohol consumption, cognitive performance, and daily functioning in an urban sample of older black Americans. J Am Geriatr Soc. 1996;44:1158-1165.

156. Leibovici D, Ritchie K, Ledesert B, Touchon J. The effects of wine and tobacco consumption on cognitive performance in the elderly: a longitudinal study of relative risk. Int J Epidemiol. 1999; 28:77-81.

157. Teri L, Hughes JP, Larson EB. Cognitive deterioration in Alzheimer's disease: behavioural and health factors. J Gerontol. 1990;42:3-10.

158. Ganguli M, Vander Bilt J, Saxton JA, Shen C, Dodge HH. Alcohol consumption and cognitive function in late life: A longitudinal community study. Neurology. 2005;65:1210-1217. 
159. Stampfer MJ, Kang JH, Chen J, Cherry R, Grodstein F. Effects of moderate alcohol consumption on cognitive function in women. $N$ Engl J Med. 2005;352(3):245-253.

160. McDougall GJ Jr, Becker H, Areheart KL. Older males, cognitive function, and alcohol consumption. Issues Ment Health Nurs. 2006;27(4):33-53.

161. Reid MC, Van Ness PH, Hawkins KA, Towle V, Concato J, Guo Z. Light to moderate alcohol consumption is associated with better cognitive function among older male veterans receiving primary care. J Geriatr Psychiatry Neurol. 2006;19(2):98-105.

162. Wright CB, Elkind MSV, Rundek T, Boden-Albala B, Paik MC, Sacco RL. Alcohol intake, carotid plaque, and cognition: the Northern Manhattan Study. Stroke. 2006;37:1160-1164.

163. Bond GE, Burr RL, McCurry SM, Rice MM, Borenstein AR, Larson EB. Alcohol and cognitive performance: a longitudinal study of older Japanese Americans. The Kame Project. Int Psychogeriatr. 2005;17(4):653-668.

164. Espeland MA, Coker LH, Wallace R, et al. Association between alcohol intake and domain-specific cognitive function in older women. Neuroepidemiology. 2006;27(1):1-12.

165. Rimm EB, Williams P, Fosher K, Criqui M, Stampfer MJ. Moderate alcohol intake and lower risk of coronary heart disease: metaanalysis of effects on lipids and haemostatic factors. $\mathrm{Br}$ Med $\mathrm{J}$. 1999;319:1523-1528.

166. Mukamal KJ, Longstreth WT Jr, Mittleman MA, Crum RM, Siscovick DS. Alcohol consumption and subclinical findings on magnetic resonance imaging of the brain in older adults: the Cardiovascular Health Study. Stroke. 2001;32:1939-1946.

167. Mukamal KJ, Kuller LH, Fitzpatrick AL, Longstreth WT Jr, Mittleman MA, Siscovick DS. Prospective study of alcohol consumption and risk of dementia in older adults. JAMA. 2003;289:1405-1413.

168. Fadda F, Rossetti ZL. Chronic ethanol consumption: from neuroadaptation to neurodegeneration. Prog Neurobiol. 1998;56(4):385-431.

169. French LR, Schuman LM, Mortimer JA, Hutton JT, Boatman RA, Christians B. A case-control study of dementia of the Alzheimer type. Am J Epidemiol. 1985;121(3):414-421.

170. Launer LJ, Feskens EJ, Kalmijn S, Kromhout D. Smoking, drinking, and thinking. The Zutphen Elderly Study. Am J Epidemiol. 1996;143(3):219-227.

171. Galanis DJ, Joseph C, Masaki KH, Petrovitch H, Ross GW, White L. A longitudinal study of drinking and cognitive performance in elderly Japanese American men: the Honolulu-Asia Aging Study. Am J Public Health. 2000;90(8):1254-1259.

172. Ruitenberg A, van Swieten JC, Witteman JC, et al. Alcohol consumption and risk of dementia: the Rotterdam Study. Lancet. 2002;359:281-286

173. Huang W, Qui L, Fratiglioni E. Alcohol consumption and incidence of dementia in a community sample aged 75 years and older. $J$ Clin Epidemiol. 2002;55:959-964.

174. Anekonda TS, Reddy PH. Neuronal protection by sirtuins in Alzheimer's disease. J Neurochem. 2006;96(2):305-313.

175. Perry E, Walker M, Grace J, Perry R. Acetylcholine in mind: a neurotransmitter correlate of consciousness? Trends Neurosci. 1999;22(6):273-280

176. Henn C, Loffelholz K, Klein J. Stimulatory and inhibitory effects of ethanol on hippocampal acetylcholine release. Naunyn Schmiedebergs Arch Pharmcol. 1998;357:640-647.

International Journal of Wine Research

\section{Publish your work in this journal}

The International Journal of Wine Research is an international, peer-reviewed open-access, online journal focusing on all scientific aspects of wine, including: vine growing; wine elaboration; human interaction with wine; and health aspects of wine. The journal provides an open access platform for the reporting
177. Orgogozo JM, Dartigues JF, Lafont S, et al. Wine consumption and dementia in the elderly: a prospective community study in the Bordeaux area. Rev Neurol (Paris). 1997;153(3):185-192.

178. Lemeshow S, Letenneur L, Dartigues JF, Lafont S, Orgogozo JM, Commenges D. Illustration of analysis taking into account complex survey considerations: the association between wine consumption and dementia in the PAQUID study. Personnes Ages Quid. Am J Epidemiol. 1998;148(3):298-306.

179. Lindsay J, Laurin D, Verreault R, et al. Risk factors for Alzheimer's disease: a prospective analysis from the Canadian Study of Health and Aging. Am J Epidemiol. 2002;156:445-453.

180. Truelsen T, Thudium D, Gronbaek M. Amount and type of alcohol and risk of dementia: the Copenhagen City Heart Study. Neurology. 2002;59(9):1313-1319.

181. Luchsinger JA, Tang MX, Siddiqui M, Shea S, Mayeux R. Alcohol intake and risk of dementia. $\mathrm{J} \mathrm{Am}$ Geriatr Soc. 2004;52(4):540-546

182. Selkoe DJ. Alzheimer's disease: genotypes, phenotypes, and treatments. Science. 1997;275(5300):630-631.

183. Marambaud P, Zhao H, Davies P. Resveratrol promotes clearance of Alzheimer's disease amyloid-beta peptides. J Biol Chem. 2005;280(45):37377-37382.

184. Grundman M. Vitamin E and Alzheimer disease: the basis for additional clinical trials. Am J Clin Nutr. 2000;71(2):630S-636S.

185. Chung KK, Dawson VL, Dawson TM. New insights into Parkinson's disease. J Neurol. 2003;250(Suppl 3):III15-24.

186. Dawson TM, Dawson VL. Molecular pathways of neurodegeneration in Parkinson's disease. Science. 2003;302(5646):819-822.

187. Maguire-Zeiss KA, Short DW, Federoff HJ. Synuclein, dopamine and oxidative stress: co-conspirators in Parkinson's disease? Brain Res Mol Brain Res. 2005;134(1):18-23.

188. Morano A, Jiménez-Jiménez FJ, Molina JA, Antolín MA. Risk-factors for Parkinson's disease: case-control study in the province of Cáceres, Spain. Acta Neurol Scand. 1994;89(3):164-170.

189. Ragonese P, Salemi G, Morgante L, et al. A case-control study on cigarette, alcohol, and coffee consumption preceding Parkinson's disease. Neuroepidemiology. 2003;22(5):297-304.

190. Gao X, Chen H, Fung TT, et al. Prospective study of dietary pattern and risk of Parkinson disease. Am J Clin Nutr. 2007;86(5): 1486-1494.

191. Fall PA, Fredrikson M, Axelson O, Granérus AK. Nutritional and occupational factors influencing the risk of Parkinson's disease: a case-control study in southeastern Sweden. Mov Disord. 1999;14(1):28-37.

192. Ono K, Hirohata M, Yamada M. Alpha-synuclein assembly as a therapeutic target of Parkinson's disease and related disorders. Curr Pharm Des. 2008;14(30):3247-3266.

193. Simons LA, McCallum J, Friedlander Y, Simons J. Alcohol intake and survival in the elderly: a 77 month follow-up in the Dubbo study. Aust NZ J Med. 1996;26:662-670.

194. Simons LA, McCallum J, Friedlander Y, Ortiz M, Simons J. Moderate alcohol intake is associated with survival in the elderly: the Dubbo study. Med J Aust. 2000;172:121-124.

195. Simons LA, Simons J, McCallum J, Friedlander Y. Lifestyle factors and risk of dementia: Dubbo Study of the elderly. Med J Aust. 2006;184(2):68-70.

of evidence based studies on these topics. The manuscript management system is completely online and includes a very quick and fair peer-review system, which is all easy to use. Visit http://www.dovepress.com/testimonials.php to read real quotes from some of our published authors. 